\title{
The liver and kidney expression of sulfate anion transporter sat-1 in rats exhibits male-dominant gender differences
}

\author{
Hrvoje Brzica • Davorka Breljak • Wolfgang Krick • \\ Mila Lovrić • Gerhard Burckhardt • \\ Birgitta C. Burckhardt • Ivan Sabolić
}

Received: 7 May 2008 /Revised: 21 October 2008 / Accepted: 25 October 2008 / Published online: 11 November 2008

(C) The Author(s) 2008. This article is published with open access at Springerlink.com

\begin{abstract}
The sulfate anion transporter (sat-1, Slc26a1) has been cloned from rat liver, functionally characterized, and localized to the sinusoidal membrane in hepatocytes and basolateral membrane (BLM) in proximal tubules (PT). Here, we confirm previously described localization of sat-1 protein in rat liver and kidneys and report on gender differences (GD) in its expression by immunochemical, transport, and excretion studies in rats. The $\sim 85-\mathrm{kDa}$ sat- 1 protein was localized to the sinusoidal membrane in hepatocytes and BLM in renal cortical PT, with the maledominant expression. However, the real-time reversetranscription polymerase chain reaction data indicated no GD at the level of sat-1 mRNA. In agreement with the protein data, isolated membranes from both organs exhibited the male-dominant exchange of radiolabeled sulfate for oxalate, whereas higher oxalate in plasma and 24-h urine indicated higher oxalate production and excretion in male rats. Furthermore, the expression of liver, but
\end{abstract}

\footnotetext{
H. Brzica • D. Breljak · I. Sabolić $(\bowtie)$

Unit of Molecular Toxicology,

Institute for Medical Research and Occupational Health,

Ksaverska cesta 2,

10001 Zagreb, Croatia

e-mail: sabolic@imi.hr

M. Lovrić

Clinical Institute of Laboratory Diagnosis,

Zagreb University Hospital Center,

Kišpatićeva 12,

10000 Zagreb, Croatia

W. Krick $\cdot$ G. Burckhardt $\cdot$ B. C. Burckhardt

Abteilung Vegetative Physiologie und Pathophysiologie,

Zentrum Physiologie und Pathophysiologie,

Universitätsmedizin Göttingen,

Humboldtallee 23,

37073 Göttingen, Germany
}

not renal, sat-1 protein was: unaffected by castration, upregulated by ovariectomy, and downregulated by estrogen or progesterone treatment in males. Therefore, GD (males $>$ females) in the expression of sat-1 protein in rat liver (and, possibly, kidneys) are caused by the female sexhormone-driven inhibition at the posttranscriptional level. The male-dominant abundance of sat-1 protein in liver may conform to elevated uptake of sulfate and extrusion of oxalate, causing higher plasma oxalate in males. Oxalate is then excreted by the kidneys via the basolateral sat-1 (males $>$ females) and the apical CFEX (Slc26a6; GD unknown) in PT and eliminated in the urine (males $>$ females), where it may contribute to the male-prevailing development of oxalate urolithiasis.

Keywords Estrogen - Oxalate · Proximal tubules . Sex hormones · Sulfate $\cdot$ Urolithiasis · Progesterone . Testosterone $\cdot$ Sex differences $\cdot$ Sexual dimorphism

\section{Introduction}

Sat-1 (Slc26a1) is a sodium-independent sulfate anion transporter that operates as an anion exchanger. In rats, mice, and humans, sat-1 mRNA was detected strongly in liver and kidney and weakly in brain, skeletal muscle, and in few other organs $[3,24,39]$. The protein from the rat liver has been expression-cloned and characterized in Xenopus oocytes [3]. Due to similar affinities determined in sat-1-expressing oocytes [3] and more recently in hepatocyte canalicular membrane vesicles [30], it was assumed that sat- 1 represents the sulfate transport system of the canalicular membrane. However, with monoclonal antibodies, the sat-1 protein was immunolocalized to the sinusoidal membrane of rat hepatocytes [38] and basolateral 
membrane of proximal tubules in the rat kidney cortex [18]. Its expression was later demonstrated in the basolateral membrane of kidney cell lines MDCK and LLC-PK1, with dileucine motif as the sorting signal for this membrane domain [40].

Along with a few other sulfate transporters, such as sodium-sulfate cotransporter NaSi-1 (Slc13a1) and NaSi-2 (Slc13a4), sat-1 plays a crucial role in intracellular uptake of inorganic sulfate in specific cells, which is then utilized in various metabolic and growth processes [31-34]. The most important metabolic role of sulfate is in conjugation processes, catalyzed by sulfotransferases, enzymes that are highest expressed in liver [11, 31]. However, the kinetic studies in rats indicated that, in the liver, sulfate is also transcellularly transported and concentrated in the bile, 1015-fold above the intracellular sulfate concentration [35]. The major players involved in these processes seem to be the two $\mathrm{Na}^{+}$-independent anion transporters, the lowaffinity sulfate-anion (chloride, thiosulfate, oxalate, succinate, cholate) exchanger in the hepatocyte sinusoidal membrane (sat- $1 ; K_{\mathrm{m}}$ for sulfate $\sim 16 \mathrm{mM}$ ) and a highaffinity sulfate-anion (bicarbonate, thiosulfate, oxalate) exchanger in the canalicular membrane $\left(K_{\mathrm{m}}\right.$ for sulfate $0.3 \mathrm{mM})[14,30]$. In kidneys, sulfate is freely filtered. However, under physiological conditions, up to $35 \%$ of the filtered sulfate is reabsorbed by the proximal tubule cells [34]. This reabsorption is mediated by $\mathrm{Na}^{+}$-dependent $(\mathrm{NaSi}-1)$ and $\mathrm{Na}^{+}$-independent processes (anion exchangers, such as CFEX/Slc26a6 and Slc26a7) at the brush-border and by sat-1 at the basolateral membrane [17, 31-34, 37]. The physiological importance of the sat-1-mediated sulfate reabsorption has been confirmed in experimental chronic renal failure, which is associated with major downregulation of the renal sat- 1 expression and significant increase of the fractional sulfate excretion [12].

Operating as an anion exchanger, sat-1 plays a crucial role in the transport of oxalate, by exchanging oxalate for sulfate or bicarbonate $[6,17]$. Oxalate is a metabolic end product, generated mostly in the liver; the metabolic pathways include the glycolate-oxidase-catalyzed transformation of glycolate to glyoxylate and lactate-dehydrogenase-catalyzed oxidation of glyoxylate to oxalate [36]. The elimination of oxalate from hepatocytes is mediated by sat1 in the sinusoidal cell membrane, in exchange for sulfate or bicarbonate. Most of the endogenous oxalate is finally eliminated by the kidneys; handling of oxalate in the rat kidneys includes filtration, partial reabsorption, and additional secretion in the proximal convoluted tubules, with the net secretion as the final outcome $[19,46]$. The secretory processes for oxalate in proximal tubules seem to be mediated by the concerted action of two anion exchangers, e.g., the basolateral sat-1 (Slc26a1) and the apical CFEX. The latter transporter functions in multiple exchange modes using oxalate, chloride, formate, sulfate, or bicarbonate as substrates $[2,16]$. The distal tubule has a minor role in oxalate secretion in rats $[19,46]$ and rabbits [44].

In humans, oxalate is known to be a major cause of urolithiasis; oxalate stones represent up to $79 \%$ of all cases $[8,48]$. Men exhibit higher oxalate excretion levels than women [26], as well as higher incidence of oxalate stones [7]; the incidence is two to threefold higher in male patients in middle age (30-59 years) but similar in both genders in young and old patients $[7,8,22,48]$. Furthermore, in a few studies of experimental nephrolithiasis in rats treated with ethylene glycol, testosterone stimulated, whereas female sex hormones inhibited, urine excretion of oxalate and formation of oxalate stones $[15,25]$. These studies thus indicated sex hormones as possible contributors to genderdependent development of oxalate nephrolithiasis in humans and rats.

Our previous studies in rats and mice indicated the presence of gender differences in the expression of Oat1 [28], Oat2 [29], Oat3 [28], and SGLT1 [41] in kidneys. We have also recently reported on higher sat-1 mRNA expression in kidneys of male rats, as studied by microarray technique [42]. The liver is a major oxalate producer, and sat-1 is a key transporter to remove oxalate (mainly in exchange for sulfate) across the hepatocyte sinusoidal membrane, whereas, in the renal proximal tubules, sat-1 plays a key role in oxalate transport across the basolateral membrane, mainly in exchange for intracellular (reabsorbed) sulfate. However, besides the previously published immunolocalization of sat-1 [17, 38], no other studies related to hormonal or metabolic regulation of sat-1 mRNA and/or protein expression in the mammalian liver and kidneys have been reported. The aim of this paper was to discern whether gender differences of sat- 1 expression exist at the level of protein, mRNA, and its transport activity in the rat liver and kidneys.

\section{Material and methods}

Animals and treatment

Adult male and female Wistar rats from the breeding colony at the Institute for Medical Research and Occupational Health in Zagreb were used in these experiments. Animals were bred and handled in accordance to the Guide for Care and Use of Laboratory Animals (National Academic Press, Washington, DC, USA, 1996). The Institutional Ethics Committee approved these studies.

Animals were used intact or were gonadectomized by scrotal (males) or dorsal (females) approach at the age of 6 weeks under general anesthesia (Narketan $80 \mathrm{mg} / \mathrm{kg}$ b.m.Xylapan $12 \mathrm{mg} / \mathrm{kg}$ b.m.). Sham-operated animals underwent 
the same procedure but without removal of organs. Both operated groups were left to recover for a period of 6 weeks before sacrificing. To test the effects of sex hormones, 3-month-old (intact) males were treated s.c. with sunflower oil (controls, $0.5 \mathrm{ml} / \mathrm{kg} \mathrm{b.m}$.) or estradiol dipropionate or progesterone (each $2.5 \mathrm{mg} / \mathrm{kg}$ b.m. per day; dissolved in sunflower oil) for 14 days.

Antibodies and chemicals

Monoclonal anti-rat sat-1 antibody (sat-1-ab) was kindly provided by Dr. L. P. Karniski, University of Iowa, USA. The antibody was used previously to immunolocalize the sat-1 protein in rat kidneys [17] and liver [38]. Monoclonal antibody against $\alpha$-actin was purchased commercially (Chemicon Int. Temecula, CA, USA). Commercial secondary antibodies included the CY3-labeled donkey antimouse (DAM-CY3) and alkaline-phosphatase-labeled goat antimouse IgG (GAM-AP). The secondary antibodies were purchased from Jackson ImmunoResearch, West Grove, PA, USA.

Narketan and Xylapan were purchased from Chassot (Bern, Switzerland). Oil solutions of estradiol dipropionate and progesterone were purchased from RotexMedica $\mathrm{GmbH}$ (Trittau, Germany) and Galenika (Belgrade, Serbia). Protease inhibitors (antipain, benzamidine, and phenylmethyl-sulfonyl-fluoride (PMSF)), calcium chelator ethylene glycol-bis( $\beta$-aminoethyl ether)- $N, N, N^{\prime}, N^{\prime}$-tetraacetic acid (EGTA), and ( $N$-(2-hydroxyethyl)piperizine- $N$ '-2-ethanesulfonic acid (HEPES) were obtained from Sigma (St. Louis, MO, USA). $\left[{ }^{35} \mathrm{~S}\right]-\mathrm{H}_{2} \mathrm{SO}_{4}(1,200 \mathrm{Ci} / \mathrm{mmol})$ was provided by Hartmann (Braunschweig, Germany). Other chemicals used were of the highest purity available and purchased from either Sigma or Fisher Scientific (Pittsburgh, PA, USA).

Determination of oxalate in blood plasma and 24-h urine

Three-month-old male and female rats were placed at 9 A.M. in separate metabolic cages with free access to tap water but without food. After $24 \mathrm{~h}$, the animals were removed and their body mass was measured. The 24-h urine volume, collected from each animal, was measured, and the urine was centrifuged at $2,500 \times \mathrm{g}$ for $15 \mathrm{~min}$ in order to remove corpuscular debris. Blood samples were obtained from the incised abdominal vena cava of anesthetized animals. The collected blood was left at room temperature for $2 \mathrm{~h}$ and then centrifuged at $3,000 \times \mathrm{g}$ for $15 \mathrm{~min}$ in order to obtain blood plasma. Oxalate in the urine and blood plasma was measured by the established method [4, 27].

Tissue fixation and immunocytochemistry

In anesthetized rats, the circulatory system was perfused via the left ventricle of the heart, first with $50 \mathrm{ml}$ of temperature-equilibrated and aerated phosphate-buffered saline (PBS; in mM: $140 \mathrm{NaCl}, 4 \mathrm{KCl}, 2 \mathrm{~K}_{2} \mathrm{HO}_{4}$, $\mathrm{pH} 7.4$ ) and then with $100 \mathrm{ml}$ of fixative (4\% paraformaldehyde in PBS). The removed liver and kidney pieces were kept in the same fixative for $24 \mathrm{~h}$ at $4^{\circ} \mathrm{C}$, followed by extensive washing in PBS, and stored in PBS containing $0.02 \% \mathrm{NaN}_{3}$ at $4^{\circ} \mathrm{C}$ until use.

Before cutting cryosections, tissue pieces were infiltrated with $30 \%$ sucrose (in PBS) overnight, embedded in tissuefreezing medium, frozen at $-25^{\circ} \mathrm{C}$, and sectioned with a Leica CM 1850 cryostat (Leica instruments, Nussloch, Germany). Four-micrometer-thick cryosections were collected on Superfrost/plus microscope slides, dried at room temperature for a few hours, and stored at $4{ }^{\circ} \mathrm{C}$ until use.

Before applying the primary antibody, liver and kidney cryosections underwent different antigen retrieval techniques, which had been optimized during the course of the study (data not shown). The liver cryosections were rehydrated in PBS for $15 \mathrm{~min}$ and then heated in a microwave oven with four cycles at $800 \mathrm{~W}$ ( $5 \mathrm{~min}$ each) in $10-\mathrm{mM}$ citrate buffer, $\mathrm{pH}$ 6. After cooling down for $20 \mathrm{~min}$ at room temperature in the same buffer, the sections were washed in PBS $(3 \times 5 \mathrm{~min})$ and used in the immunostaining procedure (steps): incubation in $0.5 \%$ (15 min) and 2\% Triton X-100 (in PBS; $30 \mathrm{~min}$ ), rinsing with PBS $(2 \times 5 \mathrm{~min})$, incubation in $1 \%$ bovine serum albumin (BSA in PBS; $30 \mathrm{~min}$ ), incubation in sat-1-ab (diluted in PBS; $1: 50$ ) at $4{ }^{\circ} \mathrm{C}$ overnight, rinsing with $0.1 \%$ Triton X-100 (10 $\mathrm{min})$ and PBS $(2 \times 5 \mathrm{~min})$, incubation in DAM-CY3 $(2.5 \mu \mathrm{g} / \mathrm{ml})$ for $1 \mathrm{~h}$ at room temperature, rinsing with $0.1 \%$ Triton $\mathrm{X}-100(10 \mathrm{~min})$ and PBS $(2 \times 5 \mathrm{~min})$, mounting in a florescence fading retardant (Vectashield; Vector Laboratories Inc., Burlingame, CA, USA), covered with the cover glass, and sealed with nail polish.

The kidney cryosections were (steps): rehydrated in PBS for $15 \mathrm{~min}$, incubated in $1 \%$ sodium dodecyl sulfate (SDS; in PBS) for $5 \mathrm{~min}$, rinsed with PBS $(4 \times 5 \mathrm{~min})$, incubated in BSA (30 min), incubated in sat-1-ab $(1: 50)$ at $4{ }^{\circ} \mathrm{C}$ overnight, rinsed with high-salt PBS $(1.8 \% \mathrm{NaCl}$ in BPS, $2 \times 5 \mathrm{~min})$, rinsed with PBS $(2 \times 5 \mathrm{~min})$, incubated in DAM$\mathrm{CY} 3$ for $1 \mathrm{~h}$ at room temperature, rinsed with high-salt PBS $(2 \times 5 \mathrm{~min})$ and PBS $(2 \times 5 \mathrm{~min})$, and covered with Vectashield and cover glass.

The immunostaining was inspected with the Opton III RS fluorescence microscope (Opton Feintechnik, Oberkochen, Germany). The images were photographed with the computer-guided Spot RT Slider digital camera and software (Diagnostic Instruments, Sterling Heights, MI, USA), and imported in Adobe Photoshop 6.0 for processing and labeling. Before taking the pictures, the software parameters were adjusted to the strongest fluorescence intensity in a set of cryosections, and all the pictures were then taken using the same parameters. 
The red color of CY3 was converted into black and white mode in order to get better contrast.

\section{Membrane preparation and Western blotting}

Animals were decapitated and exsanguinated. The liver and kidneys were removed. The main liver lobe was cut off, minced with scissors, immersed in chilled homogenization buffer (300 mM mannitol, 5 mM EGTA, 12 mM Tris-HCl, pH 7.4, $1 \mathrm{mM}$ PMSF, $0.1 \mathrm{mM}$ benzamidine, $0.1 \mu \mathrm{g} / \mathrm{ml}$ antipain), and homogenized (10\% homogenates) using a Powergen- 125 homogenizer (Fisher Scientific, New Jersey, NJ, USA) at the maximal setting: 1-min homogenization-2-min break-1-min homogenization. Total cell membranes (TCM) were isolated from the liver homogenate by differential centrifugation in refrigerated centrifuges (Sorvall Instruments, Newton, CT, USA); the cell pellet was first removed by centrifugation in a high-speed centrifuge (RC-5C, rotor SS34) at $5,000 \times g$ for $15 \mathrm{~min}$. The supernatant was then centrifuged at $150,000 \times g$ for $1 \mathrm{~h}$ (OTD-Combi, rotor T-875). The pellet, which represented TCM, was resuspended in an appropriate volume of homogenizing buffer and stored at $-70^{\circ} \mathrm{C}$ until use.

The kidneys were sagittally sliced; the cortices were manually separated and pooled, dispersed, and homogenized in the buffer described above for liver, and the basolateral membranes (BLM) were isolated by differential centrifugation and Percoll density gradient [43]. The isolated BLM were dispersed in the homogenizing buffer and stored at $-70^{\circ} \mathrm{C}$ until use. The protein was measured by the Bradford assay [5].

Before electrophoresis, samples were thawed and mixed with sample buffer (final 1\% SDS, $12 \%$ vol/vol glycerol, $30 \mathrm{mM}$ Tris-HCl, $\mathrm{pH} 6.8,5 \% \beta$-mercaptoethanol ( $\beta \mathrm{ME})$ ) and denatured at different heating temperatures $\left(37^{\circ} \mathrm{C} /\right.$ $30 \mathrm{~min}$ or $65^{\circ} \mathrm{C} / 15 \mathrm{~min}$ or $\left.95^{\circ} \mathrm{C} / 5 \mathrm{~min}\right)$. Denatured liver TCM and renal cortical BLM proteins $(60 \mu \mathrm{g}$ per well) were separated through 10\% SDS-PAGE mini-gels using the Vertical Gel Electrophoresis System and then electrophoretically wet-transferred using a Mini Trans-Blot Electrophoretic Transfer Cell (both from Bio-Rad Laboratories, Hempstead, Great Britain) to an Immobilon membrane (Millipore, Bedford, MA, USA). In order to check the efficiency of protein transfer, the Immobilon membrane was briefly stained with $0.1 \%$ Coomassie Brilliant Blue (methanolacetic acid $\left.-\mathrm{H}_{2} \mathrm{O}=50: 40: 10\right)$ and partially destained in the dye-free solution in order to expose and compare protein bands. The membrane was afterwards further destained in the same dye-free solution $(2 \times 30 \mathrm{~min})$, extensively rinsed with $\mathrm{H}_{2} \mathrm{O}$ to remove acidity. The transfer membrane was then blocked (and finally destained) by incubation in blotting buffer $(5 \%$ nonfat dry milk, $0.15 \mathrm{M} \mathrm{NaCl}, 1 \%$ Triton X-100, $20 \mathrm{mM}$ Tris- $\mathrm{HCl}, \mathrm{pH}$ 7.4), incubated in blotting buffer containing sat-1-ab $(1: 20)$ at $4^{\circ} \mathrm{C}$ overnight, rinsed with blotting buffer $(4 \times 10 \mathrm{~min})$, incubated in the same buffer containing $0.5 \mu \mathrm{g} / \mathrm{ml}$ GAM-AP for $1 \mathrm{~h}$ at room temperature, rinsed with the same buffer $(3 \times 10 \mathrm{~min})$, rinsed with PBS $(2 \times 10 \mathrm{~min})$, and then stained for alkaline phosphatase activity using the commercial 5-bromo-4-chloro-3-indolyl phosphate (BCIP)/nitro blue tetrazolium (NBT) method as an indicator (Sigma).

To control protein loading on the gels, the lower half of the Immobilon membrane, after being blocked in blotting buffer, was separated and incubated with the $\alpha$-actin-ab $\left(1: 1,000\right.$; in PBS) at $4^{\circ} \mathrm{C}$ overnight, washed, incubated in GAM-AP $(0.5 \mu \mathrm{g} / \mathrm{ml})$, and visualized using the BCIP/NBT colorimetric assay.

The labeled protein bands were evaluated by densitometry using the Quantity One 1-D Analysis Software (BioRad Laboratories, Inc.); an area of the broadest protein band of sat- 1 or $\alpha$-actin in the blot was marked, and an equal area was applied to all other bands in the same blot. The area density of each band was expressed in arbitrary units, relative to the strongest band density $(=1)$ in the corresponding control samples.

Isolation of RNA, synthesis of cDNA, and real-time RT-PCR

After decapitation and exsanguination of an animal, a slice of liver was promptly removed and immersed into RNAlater solution (Sigma). Kidneys were removed and decapsulated and a middle slice from each kidney was immediately submerged into the RNAlater solution (Sigma). The renal cortex was then dissected manually and used in further RNA isolation. Total cellular RNA from corresponding tissues was extracted using Trizol (Invitrogen, Karlsruhe, Germany) according to the manufacturer's instructions. RNA concentration and its purity were estimated by measuring the optical density at 260 and $280 \mathrm{~nm}$. The integrity of RNAs was verified by agarose gel electrophoresis after staining with ethidium bromide and visualizing under UV light. Isolated RNAs were stored at $-70^{\circ} \mathrm{C}$ until further use.

First strand cDNA synthesis was performed using the First Strand cDNA Synthesis Kit (Fermentas Int., Ontario, Canada) in accordance with manufacturer's guidelines. Total cellular RNA $(3 \mu \mathrm{g})$ was denatured at $70^{\circ} \mathrm{C}$ for $5 \mathrm{~min}$ in the reaction mixture containing $0.5 \mu \mathrm{g}$ oligo dT (18) and reverse-transcribed in total volume of $20-\mu \mathrm{l}$ reaction mixture containing $1 \times$ reverse-transcription $(\mathrm{RT})$ buffer, 20 units of ribonuclease inhibitors, $1 \mathrm{mM}$ of dNTP mix, and 40 units of Moloney murine leukemia virus reverse transcriptase. The reaction mixture was incubated at $37^{\circ} \mathrm{C}$ for $60 \mathrm{~min}$ and $72^{\circ} \mathrm{C}$ for $10 \mathrm{~min}$, respectively. cDNAs were diluted $5 \times$ in DNase-RNase-free water (Gibco-BRL, Grand Island, NY, USA) and stored at $-20^{\circ} \mathrm{C}$ until use. 
Real-time polymerase chain reaction (PCR) was performed in a 50- $\mu$ l volume using $3.3 \mu \mathrm{l}(100 \mathrm{ng})$ of the first strand cDNA template, $2.5 \mu 1$ of $20 \times$ TaqMan Gene Expression Assay mix, $25 \mu 1$ of the $2 \times$ TaqMan Universal PCR Master Mix (all from Applied Biosystems, Foster City, CA, USA), and $19.2 \mu \mathrm{l}$ of nuclease-free water. Primers and probes were designed by Applied Biosystems and supplied as TaqMan Gene Expression Assay mix containing a $20 \times$ mix of unlabeled PCR forward and reverse primers as well as TaqMan MGB probe. Assay IDs were Rn01637788_m1 and Rn00667869_m1 for sat-1 and $\beta$-actin, respectively (http://www.appliedbiosystems.com). Amplification and detection were performed using the 7500 Real-Time PCR System (Applied Biosystems). Thermal cycling conditions were: $50^{\circ} \mathrm{C} / 2 \mathrm{~min}$ and $95^{\circ} \mathrm{C} / 10 \mathrm{~min}$, followed by 40 two-step cycles of denaturation $\left(95^{\circ} \mathrm{C} / 15 \mathrm{~s}\right)$ and annealing-extension $\left(60^{\circ} \mathrm{C} / 1 \mathrm{~min}\right)$. No template control reactions, where the cDNA was substituted with nucleasefree water, were included in each run to screen for possible contaminations. To standardize the input of cDNA amount, an endogenous control, i.e., the housekeeping gene $\beta$-actin, was quantified and results were normalized to these values. Each sample was measured in duplicate. The quantification of sat-1 mRNA expression was accomplished by comparative $\mathrm{Ct}$ method using the Relative Quantification Study Software supplied by Applied Biosystems.

Transport of $\left[{ }^{35} \mathrm{~S}\right]$ sulfate in membrane vesicles from the liver and kidney cortex

To prepare liver TCM vesicles for $\left[{ }^{35} \mathrm{~S}\right]$ sulfate transport measurements, male and female Wistar rats were sacrificed by cervical dislocation under $\mathrm{CO}_{2}$ anesthesia. The liver (10 g of organ) was immediately removed and homogenized in $30 \mathrm{ml}$ buffer ( $300 \mathrm{mM}$ mannitol, $5 \mathrm{mM}$ EGTA, $0.1 \mathrm{mM}$ PMSF, $12 \mathrm{mM}$ Tris-HCl, pH 7.4). Homogenization was performed in an ice bath for $2 \times 1 \mathrm{~min}$ by an UltraTurrax. Subsequently, $70 \mathrm{ml}$ of the same buffer were added, and the homogenate was centrifuged for $15 \mathrm{~min}$ at 5,000 $\times \mathrm{g}$. The supernatant was saved and spun for $2 \mathrm{~h}$ at $48,000 \times g$. The pellet with the liver TCM was resuspended in preloading buffer (300 $\mathrm{mM}$ mannitol, $10 \mathrm{mM}$ HEPES-Tris, $\mathrm{pH} 7.4$ with or without $10 \mathrm{mM}$ oxalic acid) and stored in liquid nitrogen. Renal BLM vesicles from kidney cortex were prepared as described in [43] and preloaded with the same buffer, with or without $10 \mathrm{mM}$ oxalic acid.

Uptake of $\left.{ }^{35} \mathrm{~S}\right]$ sulfate into liver TCM vesicles was initiated by diluting $5 \mu \mathrm{l}$ of vesicle suspension $(50 \mu \mathrm{g}$ vesicle protein) with $95 \mu \mathrm{l}$ buffer containing $300 \mathrm{mM}$ mannitol, $20 \mu \mathrm{M}\left(\mathrm{TMA}_{2}\right) \mathrm{SO}_{4}, 10 \mathrm{mM}$ HEPES-Tris, $\mathrm{pH} 7.4$, and $37 \mathrm{kBq}$ of $\left[{ }^{35} \mathrm{~S}\right]$ sulfate. Uptake was conducted at $37^{\circ} \mathrm{C}$ and terminated after $10 \mathrm{~s}$ by addition of $1 \mathrm{ml}$ icecold stop solution (300 mM mannitol, $20 \mu \mathrm{M}\left(\mathrm{TMA}_{2}\right) \mathrm{SO}_{4}$,
$10 \mathrm{mM}$ HEPES-Tris, $\mathrm{pH} 7.4$,). Uptake of $\left[{ }^{35} \mathrm{~S}\right]$ sulfate into renal cortical BLM vesicles was initiated by diluting $70 \mu \mathrm{l}$ of vesicle suspension $(25 \mu \mathrm{g}$ vesicle protein) with $430 \mu \mathrm{l}$ buffer containing $150 \mathrm{mM} \mathrm{NaCl}, 20 \mu \mathrm{M} \mathrm{Na}_{2} \mathrm{SO}_{4}, 10 \mathrm{mM}$ HEPES-Tris, $\mathrm{pH} 7.4$, and $167 \mathrm{kBq}$ of $\left[{ }^{35} \mathrm{~S}\right]$ sulfate. Uptake was conducted at $37^{\circ} \mathrm{C}$ and terminated after $10 \mathrm{~s}$ by addition of 1-ml ice-cold stop solution $(150 \mathrm{mM} \mathrm{NaCl}$, $20 \mu \mathrm{M} \mathrm{Na} \mathrm{SO}_{4}, 10 \mathrm{mM}$ HEPES-Tris, $\mathrm{pH} 7.4$,). TCM or BLM vesicle suspensions were transferred to nitrocellulose filters $(0.45-\mu \mathrm{m}$ pore size, Sartorius, Göttingen, Germany), which were kept under suction in order to separate vesicles from the surrounding buffer. After rinsing with $10 \mathrm{ml}$ of stop solution, the radioactivity retained with vesicles on the filters was determined by liquid scintillation counting. Nonspecific binding of $\left[{ }^{35} \mathrm{~S}\right]$ sulfate to filters was determined in the absence of vesicles and subtracted from the counts found in the presence of vesicles.

Presentation and statistical evaluation of the data

Immunocytochemical, immunoblotting, and transport data are representative for the findings in three to four animals in each experimental group. The real-time PCR study was performed with cDNAs of independent RNA preparations from three (kidney) and four (liver) animals of both sexes. Oxalate was determined in the plasma and 24-h urine from five male and five female rats. The numeric data were expressed as means \pm SEM and were statistically evaluated with Student $t$ test at the $5 \%$ level of significance.

\section{Results}

Immunochemical characterization of sat-1-ab in rat liver and kidneys

We have first verified the previously described localization of sat-1 in rat liver [38] and kidneys [18] by immunofluorescence cytochemistry. In order to optimize the staining, in preliminary experiments, we have tested various antigen retrieval techniques including detergent (SDS) treatment and microwave heating in citrate buffer $\mathrm{pH} 3,6$, or 8 , with and without pretreating cryosections with delipidators xylol and ethanol. With liver cryosections, the highest staining intensity was obtained with heating in citrate buffer, $\mathrm{pH} 6$, while kidney cryosections required only the SDS treatment. As shown in Fig. 1a; in the liver, the sat-1 antibody strongly labeled the hepatocyte sinusoidal membrane (arrows), whereas the membrane of bile canaliculi was not stained (Fig. 1a, inset; arrowheads). In the renal cortex, the antibody strongly stained the BLM of proximal convoluted tubules (Fig. 1c). The incubation of cryosections only with the secondary antibody gave no staining (Fig. 1b,d). 


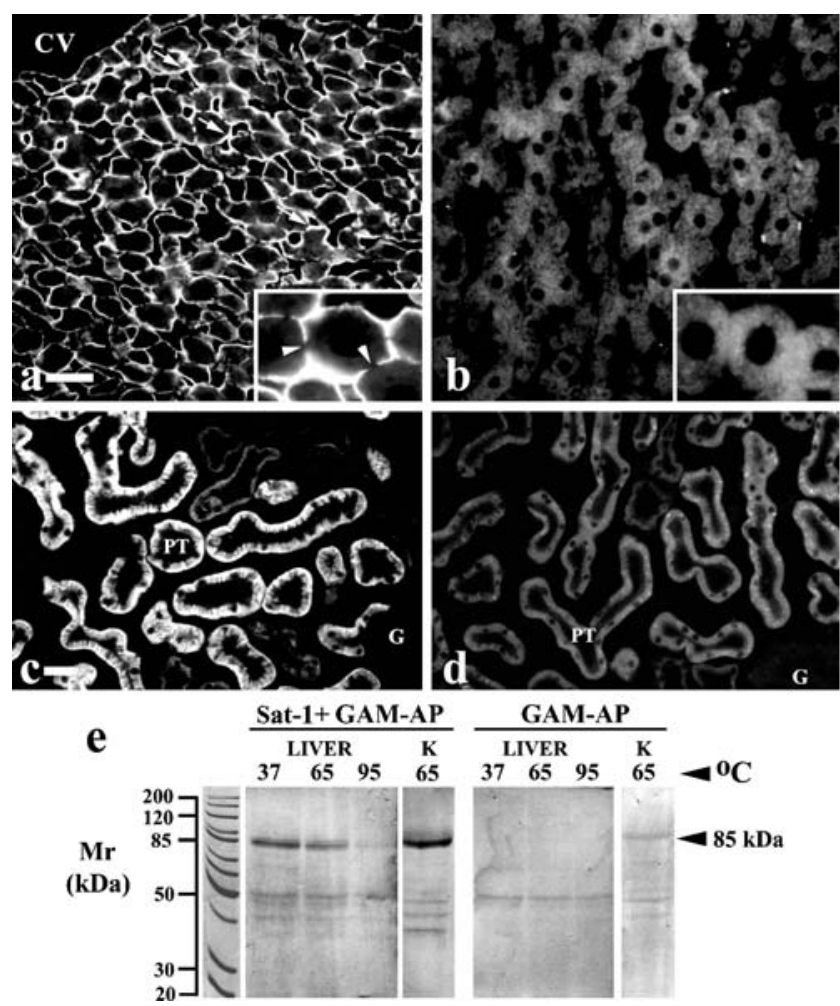

Fig. 1 Immunochemical characterization of sat-1-ab in rat liver and kidneys. a Immunocytochemistry. In the liver, the sat-1-ab strongly stained the hepatocyte sinusoidal membrane (arrows), while the canalicular membrane remained unstained (a, inset, arrowheads). c In the kidney cortex, strongly stained were the basolateral invaginations of proximal convoluted tubules (PT). b and $\mathbf{d}$ Incubation of cryosections with the secondary antibody only, gave no specific staining. $C V$, central vein; $G$, glomerulus. Bar, $20 \mu \mathrm{m}$. e Western blotting. In reducing conditions (presence of $\beta \mathrm{ME}$ ), and after heating liver TCM at $37^{\circ} \mathrm{C}$ for $30 \mathrm{~min}$, or $65^{\circ} \mathrm{C}$ for $15 \mathrm{~min}$, or $95^{\circ} \mathrm{C}$ for $5 \mathrm{~min}$ (LIVER), and kidney BLM at $65^{\circ} \mathrm{C}$ for $15 \mathrm{~min}(\mathrm{~K})$, the sat-1-ab labeled only the $\sim 85-\mathrm{kDa}$ protein band (sat-1+GAM-AP). The band in the liver membranes was strongest at $37^{\circ} \mathrm{C} / 30 \mathrm{~min}$. In nondenaturing conditions (absence of $\beta \mathrm{ME}$ ), the $85-\mathrm{kDa}$ protein band was hardly visible at any heating temperature (data not shown). The optimal denaturation conditions for the kidney BLM $\left(+\beta \mathrm{ME}, 65^{\circ} \mathrm{C} / 15 \mathrm{~min}\right)$ were determined in preliminary experiments (data not shown). Incubation with the secondary antibody alone weakly labeled the nonspecific $\sim 50-\mathrm{kDa}$ band in both liver and kidney membranes (GAM-AP), which was also visible in blots labeled with both primary and secondary antibodies

In immunoblots, in the absence of $\beta \mathrm{ME}$, the sat-1related $\sim 85-\mathrm{kDa}$ protein band was very weak at all denaturing temperatures (data not shown). Under reducing conditions (with $\beta \mathrm{ME}$ ), the sat-1-ab labeled the temperature-sensitive protein band of $\sim 85 \mathrm{kDa}$ in both liver TCM (Fig. 1e, sat-1+GAM-AP) and renal cortical BLM (not shown). The reducing conditions at $37^{\circ} \mathrm{C} / 30 \mathrm{~min}$ were optimal for presenting sat- 1 in the liver TCM, whereas the conditions at $65^{\circ} \mathrm{C} / 15 \mathrm{~min}$ were optimal for presenting sat-1 in the renal cortical BLM. These conditions were used in all further experiments. In the transfer membranes blotted only with the secondary antibody, the specific protein bands were not observed (Fig. 1e, GAM-AP).

Gender differences in the expression of liver and kidney sat-1 protein

In cryosections of male and female rat livers, we observed clear gender differences in the intensity of sat-1 staining; as shown in Fig. 2a, the hepatocyte sinusoidal membrane in males was stained stronger than in females. Accordingly, by Western blotting of TCM, the liver in male rats exhibited approximately threefold stronger $85-\mathrm{kDa}$ protein band density than in females, whereas the $\alpha$-actin band exhibited similar density in both sexes (Fig. 2b,c).

Gender differences in the sat-1 protein expression were also observed in the renal cortical convoluted tubules and in BLM isolated from the renal cortex (Fig. 3). As shown in Fig. 3a, the sat-1-ab strongly stained BLM of the cortical proximal convoluted tubules, while the overall staining intensity in the tubules of female kidneys was weaker. By Western blotting of isolated BLM, the male animals exhibited approximately twofold stronger $85-\mathrm{kDa}$ protein band than females, whereas the $\alpha$-actin was gender independent (Fig. 3b,c).

Expression of sat-1 mRNA in the rat liver and kidney cortex

Contrary to the clear male-dominant gender differences in the expression of sat-1 protein in liver and kidney cortex,
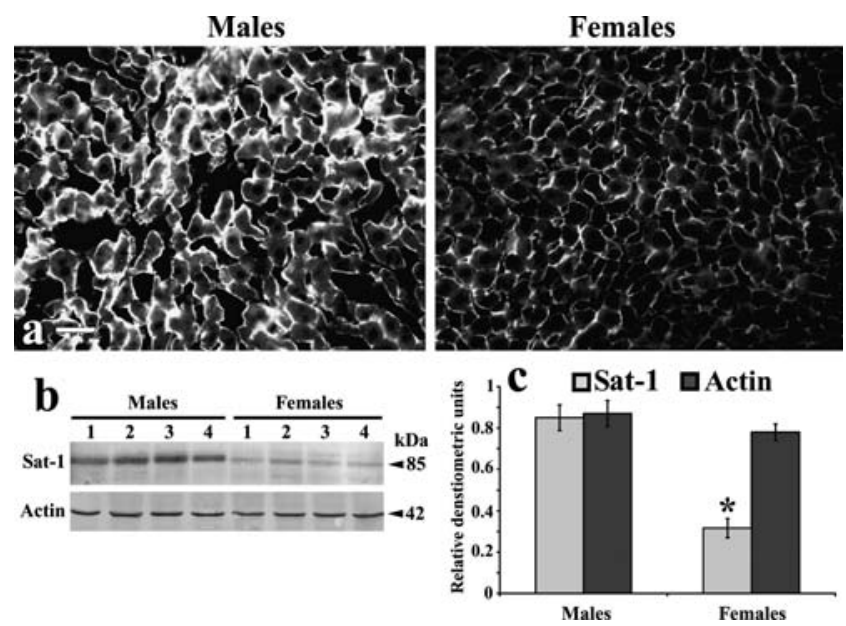

Fig. 2 Gender differences in the expression of rat liver sat-1 protein. a The sat-1-ab stained the sinusoidal membranes of hepatocytes, strongly in males and weakly in females. Bar, $20 \mu \mathrm{m}$. b. In Western blots, the sat-1-related $85-\mathrm{kDa}$ protein band in TCM from the male liver was stronger than that in females. The $\alpha$-actin protein band, used as a loading control, showed no gender difference in intensity. Each band represents an independent membrane preparation from a separate animal. c Densitometric evaluation of the protein bands shown in $\mathbf{b}$. Each bar is mean \pm SEM of the data obtained with four independent membrane preparations. Asterisk, versus the sat- 1 data in males, $P<0.05$ 

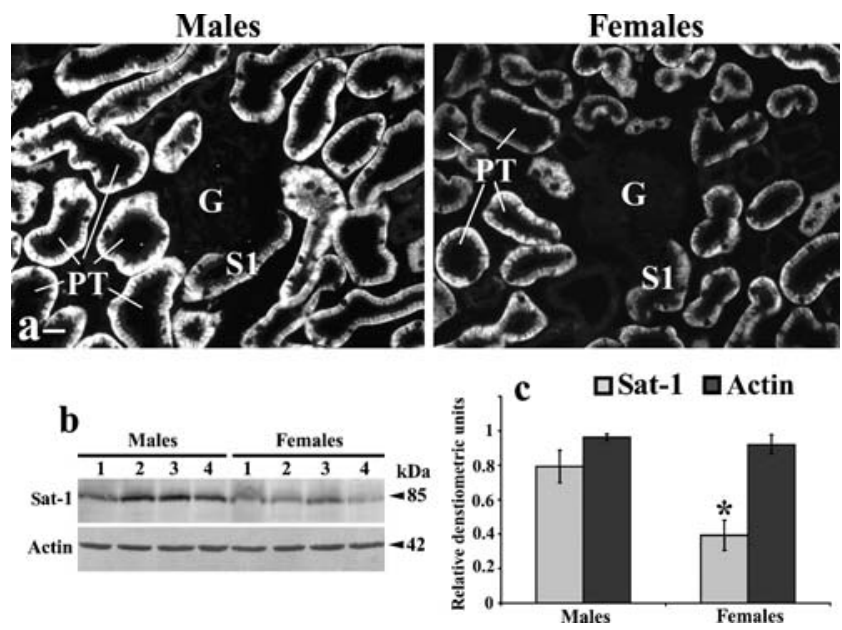

Fig. 3 Gender differences of sat-1 expression in the rat kidney cortex. a The sat-1-ab strongly stained the BLM of proximal convoluted tubules in the male kidney cortex, while, in females, the staining was clearly weaker. $G$, glomerulus; $S 1$, the initial proximal tubule segment; $P T$, proximal convoluted tubules. b In Western blots, the sat-1 protein band was strong in males and weak in females. The $\alpha$-actin protein band was similar in both genders. Each band represents an independent membrane preparation from a separate animal. c Densitometric evaluation of the protein bands shown in $\mathbf{b}$. Each bar is mean $\pm \mathrm{SEM}$ of the data obtained with four independent membrane preparations. Asterisk, versus the respective data in males, $P<0.05$

the real-time RT-PCR data, obtained with cDNA samples from four independent liver and three independent kidney cortex RNA preparations from male and female rats revealed: (a) about 40-fold lower expression of the sat-1 mRNA in the kidney (the comparison not shown) but (b) similar expression of sat-1 mRNA in livers from both sexes (Fig. 4, liver) and (c) similar expression of sat-1 mRNA in the kidney cortex of both sexes (Fig. 4, Kidney). These data indicate an absence of gender difference in sat- 1 at the mRNA level.

Oxalate-sulfate exchange in liver TCM and renal cortical BLM vesicles

The data on uptake experiments in isolated membrane vesicles from the liver and kidney cortex are summarized in Fig. 5. $\left[{ }^{35} \mathrm{~S}\right]$ sulfate uptake was followed for $10 \mathrm{~s}$ into membrane vesicles from male and female liver TCM and renal cortical BLM preloaded with $300 \mathrm{mM}$ mannitol with or without $10 \mathrm{mM}$ oxalate. With four independent liver TCM preparations from each sex, in the absence of oxalate (-oxalate), the sulfate uptake was relatively high and similar in membranes from both animal groups, whereas the oxalate-related sulfate uptake (+oxalate) was higher in the vesicles from male than from female rats; sulfate uptake in the presence of oxalate was stimulated by $81.1 \pm 29.8 \%$ and $27.5 \pm 18.0 \%$, respectively. This stimulation was much higher in preparations of the renal cortical BLM vesicles, where the intravesicular oxalate uptake in the absence of oxalate was very small in the membranes from both sexes, whereas, in the presence of oxalate, the uptake increased by $10,481 \pm 1,207 \%$ and $401 \pm 12 \%$ in males and females, respectively.

Oxalate in the blood plasma and urine of male and female rats

The preceding experiments clearly indicated the maledominant gender differences in functional expression of sat-1 protein in hepatocytes and renal cortical convoluted proximal tubules. Considering the crucial importance of this transporter for the extrusion of metabolically produced oxalate from hepatocytes and for the renal excretion of oxalate, we have tested if gender differences in the sat-1
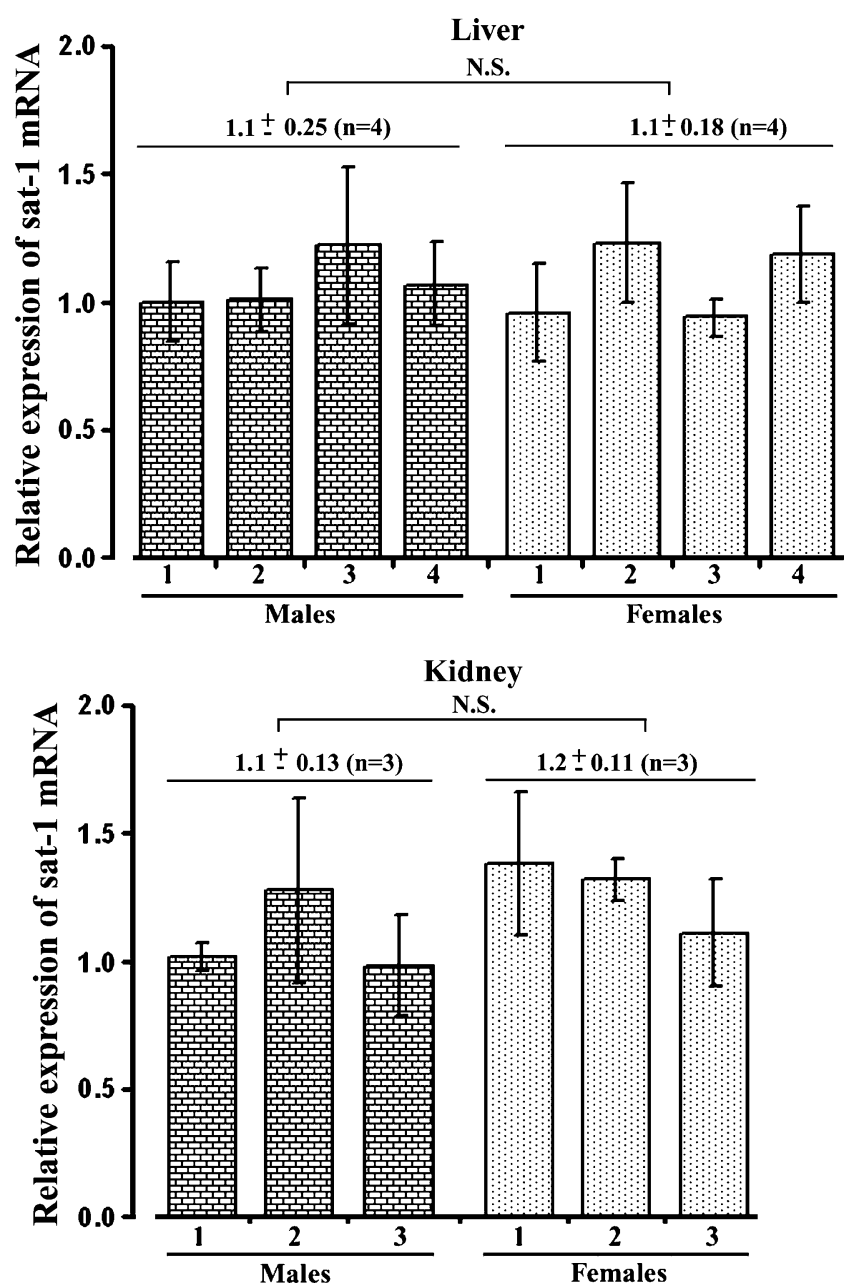

Fig. 4 Expression of sat-1 mRNA by real-time RT-PCR in the liver and kidney cortex of male and female rats. Each bar is the mean \pm SEM of duplicate determinations with cDNA prepared from the liver or kidney cortex tissue of a separate animal. The summarized data in each experimental group ( $N=4$ for the liver data and 3 for the kidney data) are given numerically above the bars. The relative expression of sat-1 mRNA in male and female livers and kidneys was similar 

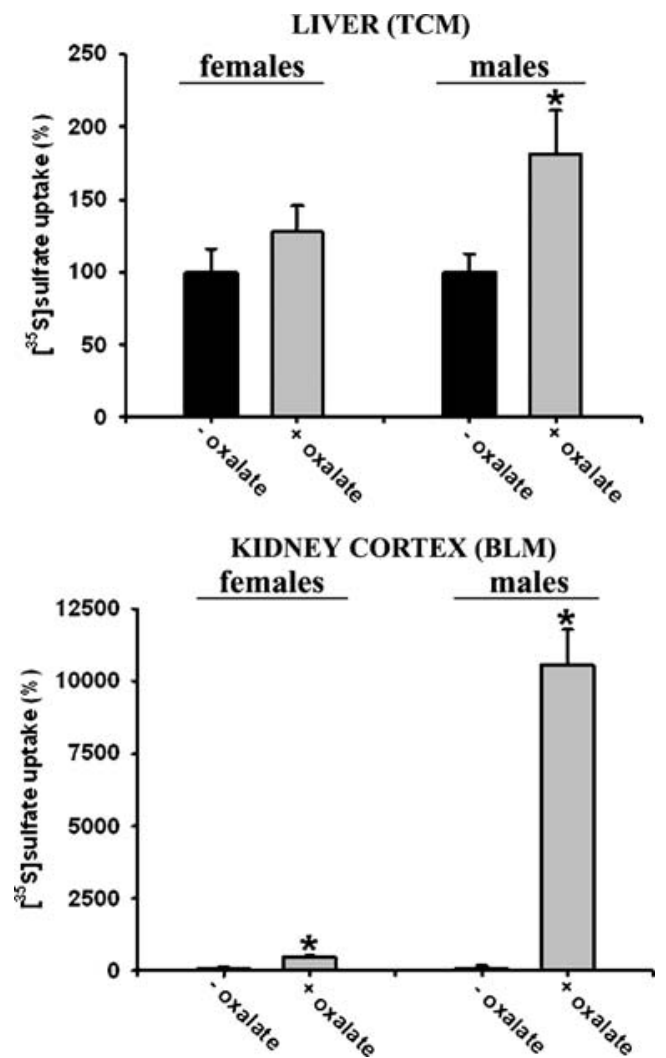

Fig. 5 Comparison of $\left[{ }^{35} \mathrm{~S}\right]$ sulfate uptake (mean \pm SEM) in TCM and BLM membrane vesicles isolated from the liver and kidney cortex, respectively, of female and male rats. The $10-\mathrm{s}\left[{ }^{35} \mathrm{~S}\right]$ sulfate uptake in both liver TCM vesicles and renal cortical BLM vesicles, preloaded without (-oxalate) or with $10 \mathrm{mM}$ oxalate (+oxalate), was measured at a total sulfate concentration of $20 \mu \mathrm{M}$. Asterisks, versus "-oxalate," $P<0.05$ $(N=4$ in each group)

expression are reflected in the plasma and urine oxalate. Indeed, from the data listed in Table 1 , we can conclude that: (a) adult male rats exhibited $\sim 80 \%$ higher oxalate levels in the plasma, (b) male and female rats excreted similar amounts of 24-h urine, (c) male rats contained

Table 1 Body mass, serum oxalate, 24-h urine volume, and urine oxalate in adult male and female rats

\begin{tabular}{lcc}
\hline Parameter & Males & Females \\
\hline Body mass $(\mathrm{g})$ & $286 \pm 6.8$ & $186 \pm 3.1^{*}$ \\
Plasma oxalate $(\mu \mathrm{mol} / \mathrm{l})$ & $30.4 \pm 2.38$ & $16.6 \pm 2.21^{*}$ \\
Urine volume $(\mathrm{ml}$ per $24 \mathrm{~h})$ & $27.9 \pm 4.28$ & $24.7 \pm 1.66$ \\
Urine oxalate $(\mu \mathrm{mol} / \mathrm{l})$ & $546 \pm 204$ & $254 \pm 48$ \\
Urine oxalate-creatinine $(\mathrm{mmol} / \mathrm{mol})$ & $130 \pm 8.1$ & $117 \pm 6.3$ \\
Urine oxalate $(\mu \mathrm{mol}$ per $24 \mathrm{~h})$ & $11.9 \pm 1.36$ & $6 \pm 0.77^{*}$ \\
\hline
\end{tabular}

Shown are means \pm SEM of the data collected from five male and five female rats. Urine was collected by keeping animals in individual metabolic cages for $24 \mathrm{~h}$. Body mass was measured, and the venous blood was taken immediately following removal of the animals from the cages

$* P<0.05$ versus the respective data in males approximately twofold higher concentration of oxalate in the urine, and (d) male rats excreted approximately twofold higher amount of oxalate in 24-h urine. In addition, $\sim 10 \%$ higher oxalate-to-creatinine ratio in the male urine indicates a higher rate of oxalate secretion by the male kidney.

Defining sex hormone(s) responsible for the observed gender differences in sat-1 protein expression in the rat liver and kidney cortex

In order to determine the sex hormone(s) responsible for the observed male-dominant gender differences in the expression of liver and kidney sat-1 protein, we have performed immunochemical experiments in gonadectomized male and female rats and in intact male rats treated with estradiol and progesterone for 2 weeks.

To test for the effect of castration on liver sat-1 protein, male rats were either sham-operated or castrated at an age of 6 weeks. Six weeks later, the animals were sacrificed and their livers were used for immunocytochemical studies and isolation of TCM for Western analysis. The sham-operated and castrated males exhibited similar intensity of the sat-1related staining in hepatocytes (Fig. 6a) and similar density of the sat- 1 and $\alpha$-actin protein bands in TCM (Fig. 6b,c). This experiment revealed androgens as an unlikely factor causing male-dominant gender differences in the expression of sat-1 protein in rat hepatocytes.

To test the effect of ovariectomy on the liver sat-1 protein, female rats were sham-operated or ovariectomized
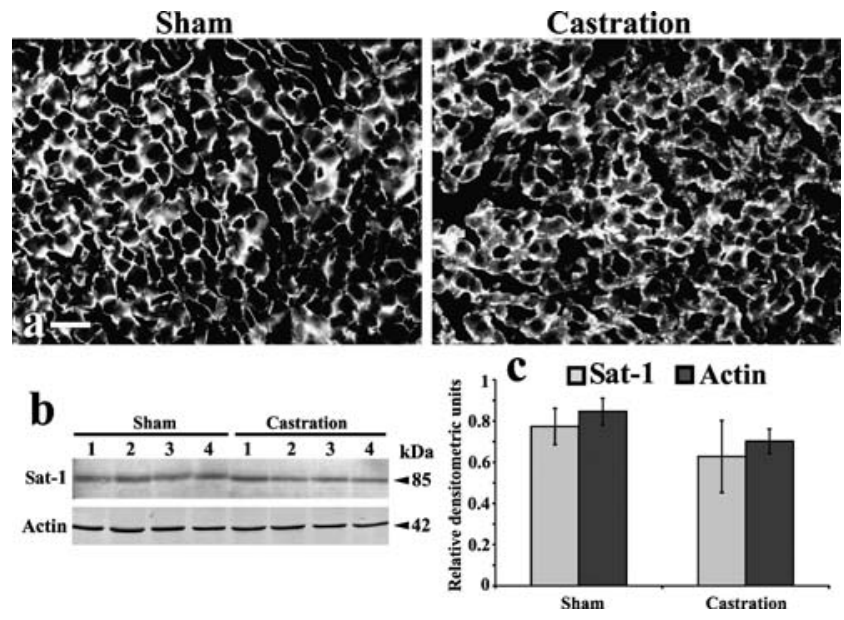

Fig. 6 Effect of castration on the expression of liver sat-1 protein. a The intensity of sat-1-related immunostaining of the hepatocyte sinusoidal membrane in sham-operated (Sham) and castrated males (Castration) was similar. Bar, $20 \mu \mathrm{m}$. b In Western blot, the protein bands of sat- 1 and $\alpha$-actin in the liver TCM from sham-operated and castrated rats were similar. Each band represents an independent membrane preparation from a separate animal. c Densitometric evaluation of the protein bands shown in b. Each bar is mean \pm SEM of the data obtained with four independent membrane preparations 

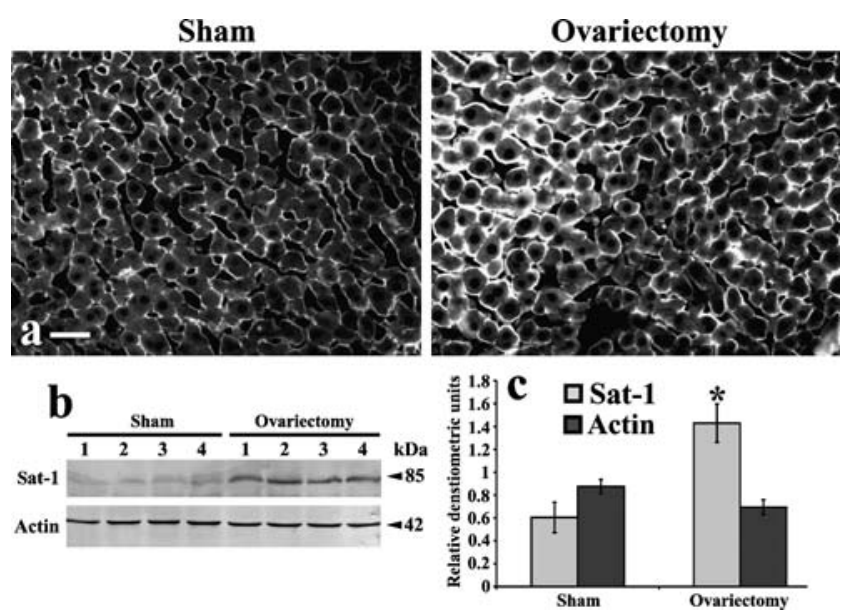

Fig. 7 Effect of ovariectomy on the expression of liver sat-1 protein. a The intensity of sat-1-related immunostaining of the hepatocyte sinusoidal membrane in ovariectomized females (ovariectomy) was higher than that in sham-operated animals (Sham). Bar, $20 \mu \mathrm{m}$. b In Western blot, the sat-1 protein band in the liver TCM from ovariectomized females was stronger than that in sham-operated controls, while the $\alpha$-actin band remained unchanged. Each band represents an independent membrane preparation from a separate animal. c Densitometric evaluation of the protein bands shown in $\mathbf{b}$. Each bar is mean \pm SEM of the data obtained with four independent membrane preparations. Asterisk, versus data in sham-operated animals, $P<0.05$

at an age of 6 weeks, and, 6 weeks later, their livers and isolated TCM were used in the respective immunochemical studies. As shown in Fig. 7a, the hepatocytes from ovariectomized females exhibited higher staining intensity compared to that of sham-operated animals. Furthermore, the sat-1-related protein band in isolated liver TCM from ovariectomized females was $130 \%$ stronger than that of sham-operated females, while the $\alpha$-actin protein band was not affected by ovariectomy (Fig. $7 b, c)$. This experiment showed that the female sex hormones may inhibit rat liver sat-1 protein expression.

In order to determine which of the female sex hormones inhibited sat-1 expression in the liver, adult males were treated with estradiol dipropionate or progesterone for 2 weeks. The immunostaining showed that, in comparison with the oil-treated controls, the sinusoidal membrane of hepatocytes in rats treated with estradiol dipropionate and progesterone was weakly stained (Fig. 8a). Similar results were obtained by Western blotting; the sat-1 protein band in TCM was strongly diminished in animals treated with estradiol dipropionate or progesterone, while the density of the $\alpha$-actin protein band remained unchanged after hormonal treatment (Fig. 8b,c). This experiment therefore showed that both estradiol and progesterone are able to downregulate the expression of sat-1 protein in the rat liver.

We have also performed similar studies of the renal sat-1 expression in gonadectomized male and female rats. However, in three independent renal cortical BLM preparations from sham-operated, castrated, and ovariectomized animals, for unresolved reasons, we could not demonstrate significant differences in the expression of sat-1 protein (data not shown).
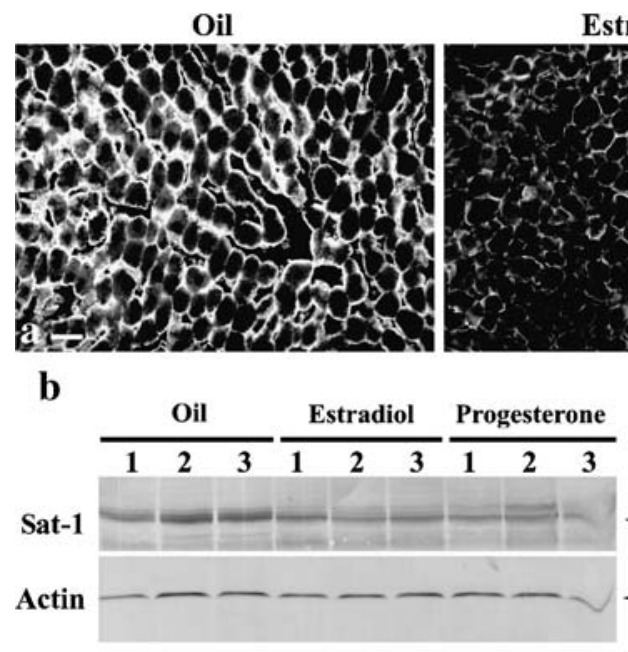

Fig. 8 Effect of estradiol and progesterone treatment in adult male rats on the expression of liver sat-1 protein. a The intensity of sat-1-related immunostaining of the hepatocyte sinusoidal membrane was strong in oil-treated and weak in estradiol-dipropionate- and progesteronetreated rats. Bar, $20 \mu \mathrm{m}$. b In Western blot, the sat-1 protein band was strong in oil-treated and weak in estradiol-dipropionate- and
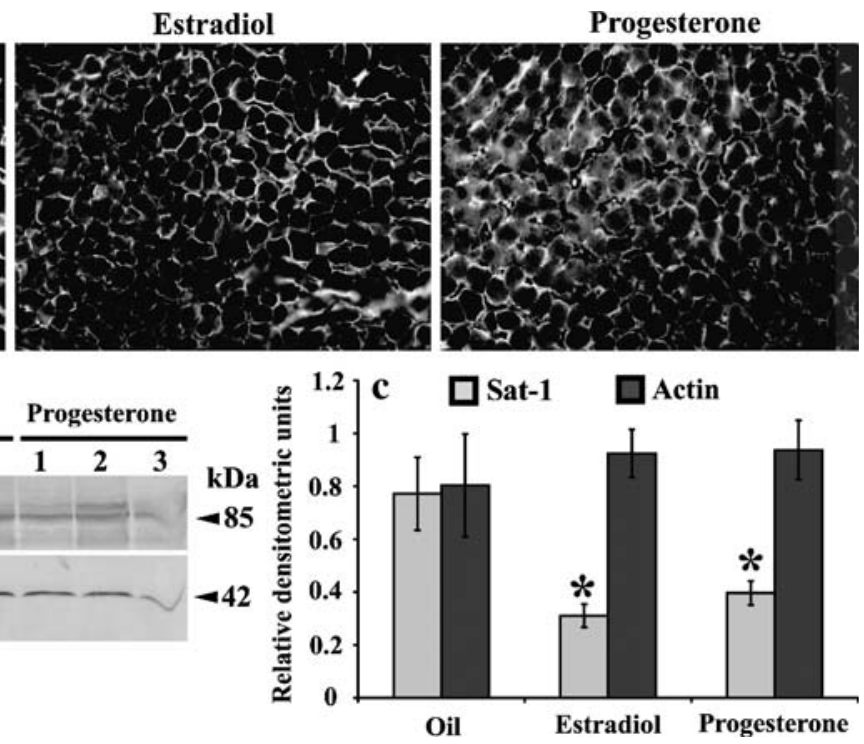

progesterone-treated rats, while the $\alpha$-actin protein band remained unchanged. Each band represents an independent membrane preparation from a separate animal. c Densitometric evaluation of the protein bands shown in $\mathbf{b}$. Each bar is mean \pm SEM of the data obtained with three independent membrane preparations. Asterisks, versus the respective data in oil-treated animals, $P<0.05$ 


\section{Discussion}

Liver is the organ where most sulfotransferases exhibit their greatest expression compared to other organs and thus is a major site of sulfation in the body [11]. All sulfotransferases utilize 3'-phosphoadenosine 5'-phosphosulfate (PAPS) as the major and rate-limiting source of sulfate in the sulfation reactions [20]. PAPS is formed from inorganic sulfate with the help of PAPS synthase (PAPSs). In mice, two isoforms of PAPSs (PAPSs1 and PAPSs2) have been previously examined for gender differences in various organs; only the kidneys and liver showed the statistically significant female-dominant mRNA expression [1]. In the rat liver, however, some sulfotransferases, like estrogen sulfotransferase in males and dehydroepiandrosterone sulfotransferase in females, tend to be much higher expressed than in the opposite gender [10]. In male and female rats, various sulfotransferases exhibited different modes of mRNA expression after hypophysectomy and after injections or infusions of the growth hormone [21], thus showing that some sulfotransferases may be regulated by growth hormones, whereas some others could possibly be affected by the sex and/or other hormones. In the human liver, however, estrogen sulfotransferases exhibit significant individual variations in protein expression but lack gender differences, indicating that, in humans, sex hormones may play only a minor role in the expression of these enzymes, while environmental and genetic factors may have a much greater impact [45]. Therefore, although there are limited indications of gender differences in the expression of some liver sulfotransferases in rats, there is no obvious relation of these sulfate-using enzymes-processes to the male-dominant expression of major sulfate-transporting protein sat-1 observed in this study.

The male-dominant gender differences in sat-1 protein may rather be related to the production and handling of oxalate in liver and kidneys. Accordingly, in the rat liver, glycolate oxidase, an enzyme which catalyzes production of oxalate, shows higher activity in males, and its activity is stimulated by testosterone and inhibited by estrogen [47]. Although it appears that these differences in enzyme activity have no significant impact on oxalate synthesis under physiological conditions, the differences become apparent under loading rats with ethylene glycol, a condition which induces hyperoxaluria and represents an experimental model to study formation of kidney stones. These experiments in rats have shown that: (a) males have a greater tendency to develop kidney stones than females, (b) ovariectomized females have higher rates of urinary oxalate excretion than sham-operated or female sex-hormonetreated animals, and (c) testosterone enhances while estrogen inhibits formation of calcium oxalate stones $[13,15,25]$.
In this report, in isolated membranes from the rat liver and kidney cortex, the sat- 1 protein was labeled as the $85-\mathrm{kDa}$ band, which is comparable to the previously detected $80-\mathrm{kDa}$ protein band in membrane fractions from the rabbit and rat renal cortex [18], probably reflecting the glycosylated form of the nascent, 704 amino acid protein (calculated $\mathrm{Mr}$ of $\sim 75 \mathrm{kDa}$ ) [18, 24, 39]. Our immunochemical studies further demonstrated clear male-dominant gender differences in sat-1 protein expression in the membranes from both rat organs, and these data were supported by the comparable transport (oxalate-sulfate exchange) in isolated membranes. However, at this point we would like to emphasize that, while our transport studies in isolated renal cortical BLM vesicles reflect the activity of sat-1 protein localized to the basolateral invaginations in proximal tubules, the studies in isolated liver TCM may reflect a cumulative transport in the vesicles of both sinusoidal and canalicular membranes, with an unknown ratio of contribution. The sulfate-anion (oxalate) exchangers, with slightly different substrate specificity and affinity for sulfate, have been described in the liver membranes; a low-affinity ( $K_{\mathrm{m}}$ for sulfate of $\left.16 \mathrm{mM}\right)$ and a high-affinity $\left(K_{\mathrm{m}}\right.$ for sulfate of $0.3 \mathrm{mM}$ ) exchanger has been detected in the sinusoidal and canalicular membranes, respectively [3, 30]. Since our immunocytochemical study showed an absence of sat-1 in the hepatocyte canalicular membrane and gender differences in sat-1 protein expression (males $>$ females) were clearly shown in the sinusoidal membrane and isolated TCM, the comparable gender-dependent sulfate transport in isolated TCM (males $>$ females) most probably reflects the transport in sat-1-positive sinusoidal membrane vesicles. Therefore, in the male liver, a higher activity of glycolate oxidase in hepatocytes [47], a higher sat-1 protein expression in the sinusoidal membrane and in isolated TCM (this report), and a higher rate of oxalate-sulfate exchange in the same membranes (this report) overall indicate a higher production and extrusion of oxalate in exchange for extracellular sulfate (or bicarbonate) than in the female liver. These phenomena could consequently lead to an enhanced level of oxalate in the blood of male rats, and this is exactly what we have observed; the concentration of oxalate in the blood plasma of male rats was significantly $(\sim 80 \%)$ higher than that in female rats. In further experiments in gonadectomized rats and in male rats treated with estradiol and progesterone, we showed that gender differences in the liver sat-1 protein expression were caused by the inhibitory action of female sex hormones, whereas androgens had no significant effect. Although the levels of oxalate in blood plasma in these rats was not measured nor we were able to find relevant data in the available literature, some previous finding in rats showed that the oxalate excretion in 24-h urine increases after ovariectomy and decreases in ovariectomized rats 
treated with female sex hormones $[13,15]$. The phenomena that: (a) castration had no significant effect and (b) ovariectomy upregulated while (c) estradiol and progesterone treatment downregulated the sat-1 protein expression in the liver, as found in our study, may have contributed to the inversely related rates of urinary oxalate excretion observed in previous studies.

A higher level of oxalate in the blood plasma in male rats represents a driving force for the higher excretion of oxalate in the urine; males and females excreted similar volume of the 24-h urine, but the urine of male rats contained approximately twofold higher concentration of oxalate and thus eliminated approximately double amount of oxalate in $24 \mathrm{~h}$ in comparison with females. In the rat kidney proximal tubules, handling of oxalate includes glomerular filtration, partial reabsorption via several brush-border transporters [23, 32], and secretion via the sat-1 protein across the basolateral membrane and via the CFEX protein across the brush-border membrane $[16,19$, $32,46]$. The male-dominant gender differences in the sat- 1 protein expression in basolateral invaginations of the cortical proximal convoluted tubules, as detected by immunocytochemical methods and confirmed by transport (oxalate/sulfate exchange) in isolated BLM vesicles, indicate the sat-1 protein as an important contributor to the enhanced secretion of oxalate in male kidneys. Our data indicate a perfect correlation among the plasma oxalate level, expression of the sat- 1 protein in the renal cortical proximal tubules, and urine oxalate; in comparison with females, male rats exhibited higher plasma oxalate level, higher renal expression of sat-1, and higher excretion of oxalate in the urine. At this point, it is worth noting that the male-dominant expression of the renal sat-1 protein may contribute to the development of oxalate nephrolithiasis in male rats; in the cases of elevated plasma oxalate due to increased production and/or intestinal absorption, the increased tubular load of oxalate enhances a chance of supersaturation and oxalate precipitation in the urinary system and formation of kidney stones. The results in our present study may well correspond to the data in ethyleneglycol-loaded rats, which showed higher incidence of oxalate stone formation in males [13, 15]. Possible gender differences in $\mathrm{Cl}^{-}$-oxalate exchanger CFEX, which in the proximal tubules works in a concert with sat- 1 and which has also been shown to play an important role in the development of urolithiasis [2, 32], have not been reported.

As shown in our real-time RT-PCR study, gender differences in sat-1 expression in both liver and kidney cortex were present at the level of protein but not at the level of mRNA, indicating posttranscriptional regulation as the major determinant of hormonal action. At the present, we cannot say if the female sex hormones inhibit the transporter synthesis and/or stimulate its degradation, or both, and whether these hormones act directly or via affecting the levels of some other hormones. The sex-hormone-driven mRNA-independent regulation of sat-1 protein expression is at odd with the recently described sex-hormone-driven regulation of numerous other renal transporters in rat and mouse kidneys via their mRNA expression [28, 29, 41, 42]. Furthermore, in our microarray study of gender differences in various renal transporters in rats, the sat- 1 mRNA expression was higher in males than in females [42]. These findings could not be reproduced in the present real-time RT-PCR study. However, the absence of gender differences for the sat-1 mRNA expression in liver was observed in both this and our microarray study (our unpublished data).

The male-dominant gender differences in the urine oxalate excretion and incidence of oxalate stones have also been observed in adult but not in young and old human patients $[7-9,22,26,48]$, thus indicating that sex hormones could be an important contributor to gender-dependent incidence of this disease in adult humans [22]. However, possible differences in the expression of sat-1 in liver and kidneys, as well as the correlation with the plasma and urine oxalate in humans, to our knowledge have not been reported. Furthermore, a number of the kidney-stoneforming diseases are known due to mutations of various genes in human population [8], but possible differences in the expression of sat-1 in liver and kidneys in these patients is also not known.

Acknowledgements The authors thank Eva Heršak and Reinhard Schirmer for technical assistance. This work was supported by grants 022-0222148-2146 from the Ministry for Science, Education, and Sports, Croatia (I.S.) and Deutsche Forschungsgemeinschaft BU 998/ 4-1 (B.C.B.).

Open Access This article is distributed under the terms of the Creative Commons Attribution Noncommercial License which permits any noncommercial use, distribution, and reproduction in any medium, provided the original author(s) and source are credited.

\section{References}

1. Alnouti Y, Klassen CD (2006) Tissue distribution and ontogeny of sulfotransferase enzymes in mice. Toxicol Sci 93:242-255

2. Aronson PS (2006) Essential roles of CFEX-mediated $\mathrm{Cl}^{-}$oxalate exchange in proximal tubule $\mathrm{NaCl}$ transport and prevention of urolithiasis. Kidney Int 70:1207-1213

3. Bissig M, Hagenbuch B, Stieger B, Koller T, Meier PJ (1994) Functional expression cloning of the canalicular sulfate transport system of rat hepatocytes. J Biol Chem 269:3017-3021

4. Blau N, Matasevic A, Lukasiewicz-Wedlechowicz A, Heizmann KW, Leumann E (1998) Simultaneous determination of oxalate, glycolate, citrate and sulfate from dried urine filter paper spots in pediatric population. Clin Chem 44:1554-1556

5. Bradford MM (1976) A rapid and sensitive method for the quantitation of microgram quantities of protein utilizing the principle of protein-dye binding. Anal Biochem 72:248-254 
6. Brändle E, Bernt U, Hautmann RE (1998) In situ characterization of oxalate transport across the basolateral membrane of the proximal tubule. Eur J Physiol 435:840-849

7. Costa-Bauzá A, Ramis M, Mostesinos V, Conte A, Pizá P, Pieras E, Garses F (2007) Type of renal calculi: variation with age and sex. World J Urol 25:415-421

8. Coe FL, Evan A, Worcester E (2005) Kidney stone disease. J Clin Invest 115:2598-2608

9. Daudon M, Donsimoni R, Hennequin C, Fellahi S, Le Mol G, Paris M, Troupel S, Lacour B (1995) Sex- and age-related composition of 10617 calculi analysed by infrared spectroscopy. Urol Res 23:319-326

10. Demyan WF, Song CS, Kim DS, Her S, Gallwitz W, Rao TR, Sloczynska M, Chatterjee B, Roy AK (1992) Estrogen sulfotransferases of the rat liver: complementary DNA cloning and ageand sex-specific regulation of messenger RNA. Mol Endocrinol 6:589-597

11. Dunn RT, Klaassen CD (1998) Tissue-specific expression of rat sulfotransferase messenger RNAs. Drug Metab Disp 26:598-604

12. Fernandes I, Laouri D, Tutt P, Hampson G, Friedlander G, Silve C (2001) Sulfate homeostasis, NaSi-1 cotransport, and SAT-1 exchanger expression in chronic renal failure in rats. Kidney Int 59:210-221

13. Green ML, Hatch M, Freel RW (2005) Ethylene glycol induces hyperoxaluria without metabolic acidosis in rats. Am J Physiol Renal Physiol 289:F536-F543

14. Hugentobler G, Meyer P (1986) Multispecific anion exchange in basolateral (sinusoidal) rat liver plasma membrane vesicles. Am J Physiol 251:G656-G664

15. Iguchi M, Takamura C, Umekawa T, Kurita T, Kohri K (1999) Inhibitory effects of female sex hormones on urinary stone formation in rats. Kidney Int 56:479-485

16. Jiang Z, Grichtchenko II, Boron WB, Aronson PS (2002) Specificity of anion exchange mediated by mouse Slc26a6. J Biol Chem 277:33963-33967

17. Karniski LP (1998) Effects of sulfate and chloride on three separate oxalate transporters reconstituted from rabbit renal cortex. Am J Physiol Renal Physiol 274:F189-F196

18. Karniski LP, Lötscher M, Fucentese M, Hilfiker H, Biber J, Murer H (1998) Immunolocalization of sat-1 sulfate/oxalate/bicarbonate anion exchanger in the rat kidney. Am J Physiol Renal Physiol 275:F79-F87

19. Knight TF, Sansom SC, Senekjian HO, Weinman EJ (1981) Oxalate secretion in the rat proximal tubule. Am J Physiol 240:F295-F298

20. Klassen CD, Boles JW (1997) The importance of 3'-phosphoadenosine 5'-phosphosulfate (PAPS) in the regulation of sulfation. FASEB J 11:404-418

21. Klassen CD, Liu L, Dunn RT 2nd (1998) Regulation of sulfotransferase mRNA expression in male and female rats of various ages. Chem Biol Interact 109:299-313

22. Kohri K, Ishikawa Y, Katoh Y, Kataoka K, Iguchi M, Yachiku S, Kurita T (1991) Epidemiology of urolithiasis in the elderly. Int Urol Nephrol 23:413-421

23. Kuo S-M, Aronson PS (1996) Pathways for oxalate transport in rabbit renal microvillus membrane vesicles. J Biol Chem 271:15491-15497

24. Lee A, Beck L, Markovich D (2003) The mouse sulfate anion transporter gene sat-1 (Slc26a1): cloning, tissue distribution, gene structure, functional characterization, and transcriptional regulation by thyroid hormone. DNA Cell Biol 22:19-31

25. Lee YH, Huang WC, Huang JK, Chang LS (1996) Testosterone enhances whereas estrogen inhibits calcium oxalate stone formation in ethylene glycol treated rats. J Urol 156(2 Pt 1):502-505

26. Lemann J, Pleuss JA, Worcester EM, Hornick L, Schrab D, Hoffman RG (1996) Urinary oxalate excretion increases with body size and decrease with increasing dietary calcium intake among healthy adults. Kidney Int 49:200-208
27. Lovric M, Granic P, Cubrilo-Turek M, Lalic Z, Sertic J (2007) Ethylene glycol poisoning. Foren Sci Inter 170:213-215

28. Ljubojevic M, Herak-Kramberger CM, Hagos Y, Bahn A, Endou H, Burckhardt G, Sabolic I (2004) Rat renal cortical OAT1 and OAT3 exhibit gender differences determined by both androgen stimulation and estrogen inhibition. Am J Physiol - Renal Physiol 287:F124-F138

29. Ljubojevic M, Balen D, Breljak D, Kusan M, Anzai N, Bahn A, Burckhardt G, Sabolic I (2007) Renal expression of organic anion transporter OAT2 in rats an mice is regulated by sex hormones. Am J Physiol Renal Physiol 292:F361-F372

30. Meier PJ, Valantinas J, Hugentobler G, Rahm I (1987) Bicarbonate-sulfate exchange in canalicular rat liver plasma membrane vesicles. Am J Physiol 253:G461-G468

31. Markovich D (2001) Physiological roles and regulation of mammalian sulfate transporters. Physiol Rev 81:1499-1533

32. Markovich D, Aronson PS (2007) Specificity and regulation of renal sulfate transporters. Annu Rev Physiol 69:361-375

33. Markovich D, Murer H (2004) The SLC13 gene family of sodium sulphate/carboxylate cotransporters. Pflügers Arch Eur J Physiol 447:594-602

34. Morris ME, Murer H (2001) Molecular mechanisms in renal and intestinal sulfate (re)absorption. J Membr Biol 181:1-9

35. Mulder GJ, Scholtens E (1978) The availability of inorganic sulphate in blood for sulphate conjugation of drugs in rat liver in vivo. Biochem J 172:247-251

36. Poore RE, Hurst CH, Assimos DG, Holmes RP (1997) Pathways of hepatic oxalate synthesis. Am J Physiol Cell Physiol 272: C289-C294

37. Pritchard JB (1987) Sulfate-bicarbonate exchange in brush-border membranes from rat renal cortex. Am J Physiol 252:F346-F356

38. Quondamatteo F, Krick W, Hagos Y, Krüger MH, Neubauer-Saile K, Herken R, Ramadori G, Burckhardt G, Burckhardt BC (2006) Localization of the sulfate/anion exchanger in the rat liver. Am J Physiol Gastrointest Liver Physiol 290:G1075-G1081

39. Regeer RR, Lee A, Markovich D (2003) Characterization of the human sulfate anion transporter (hsat-1) protein and gene (SAT1; SLC26A1). DNA Cell Biol 22:107-117

40. Regeer RR, Markovich D (2004) A dileucine motif targets the sulfate anion transporter sat-1 to the basolateral membrane in renal cell lines. Am J Physiol Cell Physiol 287:C365-C372

41. Sabolic I, Skarica M, Gorboulev V, Ljubojević M, Balen D, Herak-Kramberger CM, Koepsell H (2006) Rat renal glucose transporter SGLT1 exhibits zonal distribution and androgendependent gender difference. Am J Physiol - Renal Physiol 290: F913-F926

42. Sabolic I, Asif AR, Budach WE, Wanke C, Bahn A, Burckhardt G (2007) Gender differences in kidney functions. Pflügers Arch Eur J Physiol 455:397-429

43. Scalera V, Huang YK, Hildman B, Murer H (1981) A simple isolation method for basal-lateral plasma membranes from rat kidney cortex. Membr Biochem 4:49-64

44. Senekjian HO, Weinman EJ (1982) Oxalate transport by proximal tubule of the rabbit kidney. Am J Physiol 243:F271-F275

45. Song WC, Qian Y, Li AP (1998) Estrogen sulfotransferase expression in the human liver: marked interindividual variation and lack of gender specificity. J Pharmacol Exp Ther 284:11971202

46. Weinman EJ, Frankfurt SJ, Ince A, Sansom S (1978) Renal tubular transport of organic acids. J Clin Invest 61:801-806

47. Yoshihara H, Yamaguchi S, Yachiku S (1999) Effect of sex hormones on oxalate-synthesizing enzymes in male and female rat livers. J Urol 161:668-673

48. Yoshida O, Okada Y (1990) Epidemiology of urolithiasis in Japan: a chronological and geographical study. Urol Int 45:104 111 